\title{
Research on the Construction and Development Countermeasures of Modern Vocational Education System in Shaanxi Province
}

\author{
Fengxiang Jiang \\ Xi'an Peihua University \\ Xi’an, Shaanxi, China
}

\author{
Yufan Yuan, Lu Wang, Hanhui Yang, Changqing \\ Chen \\ Xi'an Peihua University \\ Xi'an, Shaanxi, China
}

\author{
Qiuyan Qiao \\ Xi'an Peihua University \\ Xi'an, Shaanxi, China
}

\begin{abstract}
General Secretary, Xi Jinping made important instructions on the implementation of modern vocational education in 2013, and the State Council held a working conference on modern vocational and technical education. Speeding up the development of modern vocational education is not only a national strategic deployment, but also an innovative model for the training of young talents. The development of modern vocational education is helpful to serve the local economy, improve the skills of workers and change the difficult situation of employment, and the development of modern vocational education is helpful to the improvement of the literacy and skills of Chinese labor force, and to the transform the quantity of Chinese labor force to the quality of Chinese labor force. Shaanxi, as a developed province of education, Shaanxi should establish a modern vocational education system. Shaanxi needs to vigorously develop modern vocational and technical education in order to respond to the call of national strategy, in order to meet the requirements of the transformation of economic development mode and the adjustment of industrial structure, improve the quality of vocational and technical education, train more highquality skilled talents, and resolve the situation of employment difficulties for college students.
\end{abstract}

Keywords-Shaanxi; Modern Vocational Education; Vocational Education System

\section{INTRODUCTION}

There is no "vocational and technical education" in the technical and vocational education terminology of UNESCO, which is an imported product. From "industrial education", "vocational education", "technical education" to the present "vocational and technical education", the connotation and extension of great changes has taken place. The foreign vocational education research is mainly represented by Germany. Germany has formulated the Vocational Education Law, and the practical and academic circles have jointly explored the dual vocational education system with German characteristics. Many scholars in China draw lessons from the experience of German dualism and put forward some suggestions for the development of modern vocational education system in China. In the educational environment where the quality of education is in doubt, changing the difficult situation of college students' employment, the state proposes to cultivate more modern vocational and technical talents, which makes the establishment and improvement of modern vocational education system become the focus of people's attention. Under the guidance of national policy, all parts of the country actively explore and perfect the modern vocational education system, and domestic scholars have carried on the research on modern vocational and technical education one after another.

The contents of the research on modern vocational education in the existing literature are mainly related to the basic path of the construction of modern vocational education system; the problems that should be solved in the construction of modern vocational education system; how to solve the modern vocational system in newly-built undergraduate colleges and universities; the boundaries and dimensions of modern vocational education system research; the review of modern vocational education system at home and abroad, and so on. Aisheng Zhu, Guijin Zhou, Bing Han et al. (2016) pointed out that local cities need to make every effort to build a new highland for the development of modern industry is conducive to the improvement of modern vocational education system. Modern vocational education can promote the development of regional economy, promote local employment and realize the functions of personnel training. Local cities need to meet the needs of economic construction and construct a modern vocational education system with local characteristics. There is a dilemma in the development of newly upgraded higher vocational colleges in Shaanxi Province, which needs to be solved in order to promote the healthy development of modern vocational and technical education in Shaanxi Province.

Although a large number of scholars have studied the development of modern vocational education system, there is still no perfect theoretical framework and no mature and referable practical experience. The development of cities and 
the improvement of population quality structure in different regions of Shaanxi need to vigorously develop modern vocational education. However, although there are many documents on how to develop modern vocational education in Shaanxi, most of them are empirical references, and there are not many measures that are feasible and have great effects. Therefore, there is a long way to go to improve the quality of vocational and technical education. This topic is based on the experience of Shaanxi higher education practice and exploration, in order to explore the educational theory and talent training model to adapt to the economic development of Shaanxi.

\section{THE NECESSITY AND IMPORTANCE OF THE CONSTRUCTION OF MODERN VOCATIONAL AND TECHNICAL EDUCATION SYSTEM}

The construction of modern vocational education system is the requirement of the times for the development of vocational education by the transformation of economic development mode, the upgrading of industrial structure and the adjustment of talent structure and it is also the direction of the future development of vocational education. The construction of modern vocational education system is the key to the reform and development of vocational education, and it is also an important link to perfect the higher education system of our country. Higher vocational colleges should take serving the regional economic development and promoting the transformation of economic mode as the starting point, find out their position in the construction of modern vocational education system, carry on the reform and innovation from the aspects of running a school guiding ideology, specialty setting, curriculum structure and so on, so as to play a leading role in the construction of modern vocational education system.

The construction of modern vocational education system is of cross-times significance for the development of the country. Maintaining the efficient operation of vocational education function through the modern vocational education system is helpful to train the craftsmen of large countries and provide a large number of high-level skilled talents for the development and construction of the national economy. At the same time, the steady system management mode can greatly arouse the enthusiasm of teachers and students, promote the healthy and vigorous growth of vocational schools, occupy a favorable position in the fierce school competition, and obtain a larger enrollment scale. In the future, we need to increase the economic investment and institutional tilt of the modern vocational education system in order to break through the existing concepts and institutional obstacles and promote the people's livelihood and the sustainable development of society.

\section{INVESTIGATIONS ON THE CURRENT SITUATION OF VOCATIONAL AND TECHNICAL EDUCATION IN SHAANXI PROVINCE}

Higher vocational education includes two levels of academic education: college and undergraduate. When higher vocational students graduate, they issue college and undergraduate diplomas recognized by the state, and enjoy all the treatment of ordinary college graduates. The number of higher vocational colleges in Shaanxi Province is 38, including 21 private colleges and universities. In other words, the colleges that train vocational and technical talents in Shaanxi include higher vocational colleges and private undergraduate colleges, a total of 39 colleges and universities. The Ministry of Education announced a list of 30 private universities in Shaanxi In 2019. The Ministry of Education's Action Plan for the Innovation and Development of Higher Vocational Education (2015-2018) was announced in June 2019,. 200 schools were selected in the country and 7 in Shaanxi. Shaanxi Industrial Vocational and Technical College, Yang Ling Vocational and Technical College, Xi'an Aeronautical Vocational and Technical College, Shaanxi Railway Engineering Vocational and Technical College, Shaanxi National Defense Industry Vocational and Technical College, Shaanxi Communications Vocational and Technical College, Shaanxi Vocational and Technical College were selected. Under the impetus of the national development of vocational education and the implementation of the policy of expanding enrollment in colleges and universities, vocational education in Shaanxi Province has made great progress. The number of higher vocational colleges is increasing day by day, the scale of enrollment is constantly expanding, the benefit of scale is prominent, the reform of personnel training mode is accelerated, and the quality and efficiency are improved.

\section{PROBlEMS AND CAUSES OF VOCATIONAL AND TECHNICAL EDUCATION IN SHAANXI PROVINCE}

\section{A. The Cognition of Vocational and Technical Education is not in Place.}

Society's cognition of vocational and technical education is to lower the level of vocational and technical education and train all skilled workers. In the future, the social status is low and unwilling to send children to vocational and technical colleges. Many higher vocational colleges do not fully understand the importance of vocational and technical education, do not understand the social and national demand for vocational and technical personnel, and the lack of awareness seriously affects the healthy development of vocational and technical education.

\section{B. A Strong Competitive Strength has not been Formed}

Although there are many vocational and technical education colleges in Shaanxi, but the characteristics are not prominent, many higher vocational colleges still run subject education, cannot realize the application of technical education, in the professional setting, talent training, teacher matching is much the same, the quality of talent training is low, in the talent market students do not master a relatively suitable skill, lack of excellent labor skills, affecting the employment situation of college students. It is difficult for vocational and technical colleges to form strong competitive strength.

\section{Professional Construction Separated from Professional Position Group}

Higher vocational colleges are also seeking development in exploration, there are few experiences that can be used for reference, the orientation of training objectives in the process 
of professional construction, the proportion of theoretical knowledge and practical skills are still in the process of groping, so when setting up specialties, it is not accurate to grasp the organic combination of professional packaging, professional training objectives, curriculum design, teaching content and social professional posts (groups). As a result, the professional setting cannot be closely combined with the needs of the society, and the connection between the whole professional construction and the professional post group is not enough close, resulting in the practicability and pertinence of talent training.

\section{CONSTRUCTION AND DEVELOPMENT \\ COUNTERMEASURES OF MODERN VOCATIONAL EDUCATION SYSTEM IN SHAANXI PROVINCE}

\section{A. Reposition Vocational and Technical Education.}

In the decisive stage of building a well-off society by 2020 and even by 2030, it is urgent to accurately position vocational education and training and take more coordinated steps to promote it. There are four aspects that need to be considered:

(1) Lifelong learning. Vocational education and training should be placed in the framework of lifelong learning system and learning society. If a country or region only popularizes general education in an all-round way and does not have vocational education facing the needs of human resources market, it is difficult to imagine how to support the sustainable development of economy and society.

(2) Coordinated development. Vocational education and training will be coordinated with higher education and continuing education. Vocational education will be one of the area's most directly and closely related to the external labor market in the education system. To promote the construction of a learning society, it is necessary to form a flexible system conducive to employees receiving vocational education and training. In fact, it is like an "overpass" in all directions. Even if people miss a certain stage of study, they still have the opportunity to compensate. (3) Integration and cooperation. Vocational education and training must follow the road of integration of production and education and cooperation between schools and enterprises-at present, it is probably not seen that vocational education in any country or region can achieve benign development under the condition that the government is completely laissez-faire and driven by the demand of enterprises alone. At the same time, there are few successful examples of vocational and technical schools arranged by the government, and there is no successful example of the participation of industry enterprises.

(4) Diverse forms of business. Vocational education and training will become an active field of diversified education new business type-it is expected that the demand for users of vocational education will become a frame of reference for the survival and development of all service supply models in the future. Vocational education and training behavior will range from free and inclusive public welfare services to accurately position charging services, which need to be more actively locked, adapted to, guided, stimulated or even "manufactured" users' demand. There will be a vocational education and training project of "high cost sharing" and "high personal income", and there will be a model mechanism of customizing high-skilled professionals and master experts for industry enterprises.

\section{B. Speeding up the Top Level Design of Vocational and Technical Education}

Since 2019, China will start the pilot work of "Certificate of several Vocational skill levels" (that is, $1 \mathrm{X}$ Certificate) in vocational colleges and universities. By 2022, the teaching conditions of vocational colleges and universities will basically reach the standard, and a large number of ordinary undergraduate colleges and universities will change to the applied type. It is necessary to promote the transformation of vocational education from the pursuit of scale expansion to the improvement of quality, greatly improve the modernization level of vocational education in the new era, and provide highquality human resources support for promoting economic and social development. Shaanxi needs to explore the innovation and reform of vocational education in order to better meet the needs of the development of the times. Only when the education authorities, schools and enterprises make joint efforts to do a good job in the top-level design and planning of vocational education, can more people enter the campus of vocational education, become the backbone of the development of manufacturing industry, and take multiple measures to construct the characteristic vocational education system in Shaanxi.

\section{Reforming the Teaching Mode of Vocational and Technical Education}

Vocational education has entered the climax of a new round of curriculum reform. Vocational education must explore new ideas, construct a new mode of education and teaching, improve students' vocational ability, and train new creative and practical talents for the society. Shaanxi applied technology colleges and universities need to deepen the reform of education and teaching. It is necessary to firmly establish the concept of educational development with improving quality as the core, run the socialist core values through the whole process of education and teaching, build a team of "doublequalified" teachers, perfect the quality evaluation system, strengthen international exchanges and cooperation, and constantly expand the international vision of vocational and technical education.

\section{Optimizing the Management Mode of Vocational and Technical Education}

The modern vocational education system is basically established, the policies and regulations are more perfect, the relevant standards are more scientific and standardized, and the supervision mechanism is more perfect. Policies to guide and encourage the participation of social forces are sounder. The concept of talents in the whole society has been significantly improved, and the atmosphere of supporting and participating in vocational education has become stronger. Shaanxi government and education departments need to further simplify the administration and decentralization, strengthen the macro management of vocational and technical education, coordinate 
as a whole and guide the classification, perfect the internal governance structure of applied vocational and technical colleges and universities, and improve the supervision and evaluation system. In order to effectively improve the educational level of vocational and technical colleges in Shaanxi Province, we must strengthen the management of vocational and technical colleges, optimize the management mode of vocational and technical education, and carry out institutionalized management.

\section{E. Innovating the Holding Mode of Vocational and Technical Education}

It is necessary to establish a flexible learning system conducive to vocational education and training for all workers, serve national learning, lifelong learning, and promote the construction of a learning society. Shaanxi needs to innovate the mode of vocational and technical education and realize the diversification of participants in vocational and technical education. Encouraging the collectivization of vocational education and the collectivization of vocational education is an effective mode to promote the deep cooperation and seamless connection between schools and enterprises, which has become an effective way for all vocational colleges to develop vocational education.

\section{CONCLUSION}

In a word, the vocational education system of Shaanxi Province needs to strengthen the external adaptability and internal coordination, train the vocational skilled talents of Shaanxi regional economic development, realize the strategy of Shaanxi's economic and social development, systematically plan vocational education, strengthen the top-level design of vocational education, clarify the road map, timetable, concentrate on tackling the key and difficult problems, and strive to make a breakthrough in solving the bottleneck problem of restricting the development of vocational education. It is necessary to strengthen the guidance of public opinion, promote the formation of a long-term mechanism for publicizing vocational education and technical skills, create a good atmosphere for the reform and development of vocational education, and form a modern vocational education system with "Shaanxi Characteristics".

\section{REFERENCES}

[1] [1] Wenbin Qu. Exploration on the Construction of Modern Vocational Education System in Shaanxi Province [J]. Journal of Yang Ling Vocational and Technical College, 2015 (1): 61-63.

[2] Xueyi Liu. Exploration on the Construction of Modern Vocational Education System with Characteristics in Shaanxi Province [J]. Literature Education, 2018: 60 -61

[3] Sun Jicai. Regional Economic and Social Development and Reconstruction of Modern Vocational Education System: A Case Study of Lianyungang Vocational Education [J]. Lianyungang Normal College, 2013,31 (3): 85- 88

[4] Zhou Xuemei. To construct a new coordinate of the development of modern vocational education in China-based on the theoretical perspective of "field" [J]. Journal of Beijing Vocational College of Finance and Trade, 2016 (6): 35 -30

[5] Zou Yulan. Thinking and exploring on the Construction of Modern Vocational Education system: a case study of Vocational Education in Guangdong Province [J]. Exploration of higher Vocational Education, 2013 (2): 11- 13.

[6] Wang Zhenhua. Exploration and reflection on the Construction of Modern Vocational Education system: a case study of Henan Fiscal and Taxation College [J]. Henan Provincial College of Finance and Taxation, 2013,27 (6): 50 - 52.

[7] Wang Zhenhua. Exploration and reflection on the Construction of Modern Vocational Education system [J]. Henan Education (Vocational Education Edition), 2013 (3): 22-23. 